\section{Barex SciencePark Research, Organization \& Counseling \\ Global Journal of Foreign Language Teaching}

Volume 7, Issue 4, (2017) 150-154

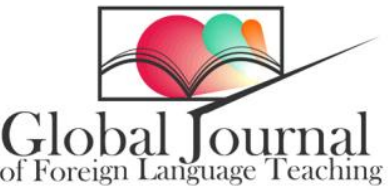

www.gjflt.eu

\title{
The effect of vocabulary size in oral productions on the speaking proficiency of EFL learners
}

Ehsan Kazemi*, Payame Noor University, No. 82 Niyayesh Alley, Bistmertri Vahdat Street, Semnan 3514948681, Iran.

\section{Suggested Citation:}

Kazemi, E. (2017). The effect of vocabulary size in oral productions on the speaking profici ency of EFL learners. Global Journal of Foreign Language Teaching. 7(4), 150-154.

Received date 02 August, 2017; revised date September 02, 2017; accepted date October 05, 2017. Selection and peer review under responsibility of Assoc. Prof. Dr. Ali Rahimi, Bangkok University, Thailand. ${ }^{\circ} 2017$ SciencePark Research, Organization \& Counseling. All rights reserved.

\begin{abstract}
This s tudy inves tiga tes the effect of using a bigger vocabula ry size in oral class room presentations on the speaking proficie ncy of students in English as a foreign language. The study was conducted with 30 freshman students doing theirlistening and speaking course in Semnan University. For the entire course of 12 weeks, the students in the experimental group were asked to present their productions in terms of the vocabulary they employed, which was also the focus of the teacher's evaluation in each session. At the end of the course, they were interviewed for their proficiency in speaking. The descriptive and inferential calculations were done based on a modified version of an oral proficiencyinterview scale sugges ted by Penny Ur. The answers were recorded and their fluency and accuracy were graded. The results suggest thats tudents with a vocabularyrich production improved theirspeaking proficiency in English more than other students did.
\end{abstract}

Keywords: Vocabula ry size, speaking proficiency, production, fluency, a ccura cy, inte rview.

\footnotetext{
* ADDRESS FOR CORRESPONDENCE: Ehsan, Kazemi, Payame Noor University, No.82 Niyayesh alley, Bistmertri Vahdat street,
} Semnan, 3514948681, Iran. E-mail address: ehsan.kazemi2013@yahoo.com / Tel.:+98-91-93-741-089 


\section{Introduction}

It is a great wish for any language learner to be fluent and accurate in the language they are studying. For sure, there are many elements involved in reaching the level of proficiency in a language. Though some researchers (Brown, Iwashita, McNamara \& O'Hagan, 2008; Norris \& Ortega, 2000; Ortega, 2003) discussed some contributing elements such as grammatical accuracy, lexical diversity and fluency, there should be more factors which worth investigating. We should also bear this in mind that since most of the research in this area deals with English language acquisition, we are unsure to what extent we can generalise it to languages with different typology.

\section{Literature Review}

\subsection{Speaking proficiency}

Speaking proficiency may be defined differently from researcher to researcher, and proficient speakers are normally labeled as 'good', 'fluent', 'knowledgeable', 'bilingual', 'competent' and so on (Galloway, 1987). A noticeable bulk of literature has investigated the features of oral proficiency, for instance, Higgs and Clifford (1982) define proficiency according to scores obtained from rating scales and feedback on ratings from teachers in qualitative manner, while others such as Freeman (2006) and Magnan and Sieloff (1988) evaluated the learners' performance through objective assessments. Adams (1980) researched the relationship between global speaking score and factors such as accent, comprehension, vocabulary, fluency and grammar in the test of speaking.

De Jong and Van Ginkel (1992) gathered speaking test data from 25 students in order to investigate the effect of different aspects of proficiency on the global proficiency score and the outcome of the research indicated that in lower levels it is the pronunciation which contributes the most to global proficiency but in higher levels fluency proves to be more important.

McNamara (1996) concluded, in an analysis using rash item modeling, that among the five analytic scales of comprehension and fluency, intelligibility, expression and grammar and appropriateness it is the grammar and expression which contribute the most to the global score of proficiency.

The aforementioned studies analysed the proficiency level according to feedbacks from teachers but not based on what learners can produce. Some researchers consider only one or two features of oral proficiency. Some other studies, on the other hand, investigated a wider variety of factors.

Magnan and Sieloff (1988) conducted an analysis on oral proficiency interview (OPI) scripts of 40 language students in terms of different types of grammatical error. The result indicated a strong relationship between the percentage of grammatical error and OPI scores, but such relationship was not always the same. It varies depending on the type of error and the level of students.

Freeman (2006) gathered oral data from five Chinese learners of English over four month and did analysis in terms of fluency, lexical complexity and accuracy. The results demonstrated that although learners became more fluent, accurate and complex, each of them had his own way regarding the rate of improvement.

\subsection{Vocabulary size}

Measuring the domain of vocabulary size in English as foreign language learners has come in to spot light for the past three decades. Laufer and Goldstein (2004) and Milton (2009) are under the impression that it is very crucial for a learner to acquire sufficient vocabulary size in order to master a language, for instance, Milton (2009) demonstrated a positive significant relationship between vocabulary size and proficiency in speaking. However, some other research emphasised such relation for listening (Staehr, 2008) and writing skill (Staehr, 2008). Laufer and Kalovski (2010), on the other hand, showed that a good vocabulary size contributes to reading comprehension ability. Apparently, it 
is a necessity to have a wider domain of words for a person who wants to master a lan guage. Alderson $((2005$, p. 88$)$ makes the remark that language ability is to a large extent a function of vocabulary size'.

There have also been some investigations dealing with how we can measure the vocabulary size of learners accurately. Nation and Webb (2011) emphasised that it is an important task for L2 vocabulary researcher to develop valid reliable measurement of the English vocabulary size.

\section{Methods}

\subsection{Participants}

This study involves 30 freshmen students of English language and literature at Semnan University who are passing a speaking course of 12 weeks, so our sampling was based on the availability issue. At the beginning of the course, these 30 students were divided into a couple of 15 student classes. They also had to undergo an interview to determine their speaking proficiency and to make sure that the two classes are homogeneous.

\subsection{Instrumentation}

The students were interviewed twice. The first interview was at the beginning which served as both a homogeneity test and a pretest, a list of 29 questions whose validity is well established. We asked each students these questions and the answers were recorded. The second interview consisted of a list of 15 questions which were based on the material they have worked on during the semester. Students' speaking proficiency was graded based on a modified version of an OPI scale suggested by Penny Ur (1996).

\subsection{Procedure}

The material for both the experimental and control group is the same. Both classes work under the framework of the book 'passages 2' and they keep on based on the same syllabus. Every session students were supposed to have oral production and present it to the class according to the topics included in their book they do it on a regular turn. The students in the experimental class were asked to enrich their production with as many vocabularies as they can, and this feature of their presentation was being monitored and guided during the semester. But, in our control group, there was no such focus on the vocabulary size. After 12 weeks of instruction, students were interviewed again but this time the questions are on the familiar topics that both groups had worked on in their course book. The answers were again recorded and the fluency and accuracy of the spoken answers were graded by two raters based on the Penny Ur's scale.

\section{Results}

Descriptive statistics and comparing the mean scores of the experimental and control groups for pre-test and post-test are demonstrated in Table 1.

Table 1. Descriptive statistical values

\begin{tabular}{lcc}
\hline & Mean & SD \\
\hline Control - pre-test & 6.7333 & 1.1629 \\
Control - post-test & 6.8000 & 1.014 \\
Experimental - pre-test & 6.2667 & 1.032 \\
Experimental - post-test & 7.4667 & 1.4074 \\
\hline
\end{tabular}


At the beginning, the mean score of the two groups varied slightly. The control group (6.7333) and experimental group (6.2667) which indicate that the difference in means of the two groups at this stage is not significant but after the treatment experimental group achieves a mean score of 7.4667 obtaining an increase in 1.2. The result of the $T$-test $(t=4.938)(p<0.001)$ also showed a significant difference for the post-test (Table 2).

\begin{tabular}{cccccc}
\multicolumn{7}{c}{ Table 2. The results of $T$-test } \\
\hline SD & $N$ & $\mathrm{df}$ & $t$ & Sig. \\
\hline -test & 0.94112 & 15 & 14 & 4.938 & 0.001 \\
\hline
\end{tabular}

\section{Conclusion}

The core purpose of this study was to investigate the effect of vocabulary size of oral productions on the speaking proficiency of English as a foreign language (EFL) learners. Our treatment fostered the fluency in some students and accuracy in some others. More importantly, it produced a major finding that our experimental group achieved a significantly higher score than the control group which indicated that our treatment was effective. Comparison between the control group and experimental group at the pre-test stage was not significant, but after the treatment post-test, the experimental group achieves an increase in 1.2. The result of the $T$-test showed also a significant difference for the post-test.

Considering the uncontroversial role of vocabulary as an essential component of input in language learning (Clouston, 2013) and the central role, the vocabulary size plays as the medium of that vital input (Richards, 2005). The intent of the current study was to provide a glimpse of the effect of vocabulary size of oral productions on the speaking proficiency of Iranian EFL learners. The result of this study could be useful to teachers, book designers, learners and policy makers. Further research into the effect of vocabulary loaded production on speaking proficiency can explore deeper in this issue to find which aspect of speaking proficiency is influenced more.

\section{References}

Adams, M. L. (1980). Five co-occurring factors in speaking proficiency. In J. R. Firth (Ed.), Measuring spoken language proficiency (pp. 1-6). Washington, DC: Georgetown University Press.

Alderson, J. C. (2005). Principles and practice in language testing. Keynote Address at RATE-QUEST Conference, Cluj, Romania.

Galloway, V. (1987). From defining to developing proficiency. Lincolnwood, IL: National Textbook Company.

Higgs, T. V \& Clifford, R. T. (1982). The push toward communication. In T. V. Higgs (Eds.), Curriculum, Competance and the foreign language teacher. The ACTFL foreign language education series (pp. 57-79). Skokie, IL: National Textbook Company.

De Jong, J. H. A. L \& Van Ginkel, L. W. (1992) Dimensions in oral foreign language proficiency. In J. H. A. L. de Jong (Ed.), The construct of language proficiency (pp. 112-140). Amsterdam, Netherlands: John Benjamins.

Freeman, L. D. (2006) The emergence of complexity, fluency, and accuracy in the oral and written production of five Chinese learners of English. Applied Linguistics, 27, 590-619.

Laufer, B. \& Goldstein, Z. (2004). Testing vocabulary knowledge: Size, strength and computer adaptiveness. Language Learn, 54, 399-436.

Laufer, B. \& Kalovski, R. G. C. (2010). Lexical threshold revisited: Lexical text coverage, learners' vocabulary size and reading comprehension. Reading in a Foreign Language, 22(1), 15-30.

Clouston, L. M. (2013). Tea ching vocabulary. Al exandria, VA: TESO L International Association. 
Magnan \& Sieloff, S. (1988). Grammar and the ACTFL oral proficiency interview: discussion and data. The Modern Language Journal, 72(3), 266-276.

Milton, J. (2009). Measuring second language vocabulary acquisition. Bristol, UK: Multilingual Matters.

McNamara, T. (1996). Measuring second language performance. Harlow, UK: Addison Wesley Longman.

Nation, I. S. P. \& Webb, S. (2011). Researching and analyzing vocabulary. Boston, Massachus etts: Heinle Cengage Learning. ISBN 10:1-111-07118-7.

Norris. J. M \& Ortega. L (2000). Effectiveness of L2 instruction: a research synthesis and quantitative metaanalysis. 2000 Language Learning Research Club, 50(3), 417-528.

Ortega. L. (2003) Syntactic complexity measures and their relation to oral proficiency in Japanese as a foreign language. Language Assessment Quarterly, 2(4), 151-170.

Richards, J. C. (2005). The role of textbooks in a language program. Cambridge, UK: Cambridge University Press.

Staehr, L. S. (2009). Vocabulary knowledge and advanced listening comprehension in English as a foreign language. Studies in Second Language Acquisition, 31(4), 1-31. 